\title{
Conventional transbronchial needle aspiration cytology as a diagnostic tool in patients with suspected lung cancer - Our experience at a tertiary care center.
}

\author{
Chauhan R. ${ }^{1}$, Awasthi S. ${ }^{2}$, Arora D. ${ }^{3 *}$, Ahmed F. ${ }^{4}$, Joshi H. ${ }^{5}$, Garg I. 6 \\ DOI: https://doi.org/10.17511/jopm.2020.i07.01
}

1 Rashmi Chauhan, Assistant Professor, ${ }^{2}$ Seema Awasthi, Professor and Head, 3* Deepti Arora, Associate Professor, ${ }^{4}$ Faiyaz Ahmed, Professor, ${ }^{5}$ Himanshu Joshi, Associate Professor, ${ }^{6}$ Ina Garg, Post-Graduate. All the authors are affiliated with the Department of Pathology, Teerthanker Mahaveer Medical College and Research Center, Moradabad, Uttar Pradesh, India

Background: Conventional transbronchial needle aspiration (c-TBNA) is a minimally invasive bronchoscopic technique used to obtain cytological samples from peribronchial lesions and mediastinal lymph nodes. However, the concern about its efficacy and the advent of newer techniques have led to the underutilization of this time tested and cost-effective modality. Objective: The present study was aimed to assess the diagnostic yield of c-TBNA in suspected cases of lung cancer. Method: c-TBNA smears received from January 2017 to February 2020, with clinical-radiological suspicion of lung malignancy were retrospectively analyzed. Result: A total of 22 cases were reviewed. The mean age of the study population was 57.54 years, with a male-female ratio of $\sim 2: 1$. The adequate aspirate was obtained in 19/22 (86\%) cases. The overall diagnostic yield of C-TBNA was $82 \% .14 / 19(74 \%)$ cases were positive for malignancy, non-small cell lung carcinoma being the most common malignancy diagnosed (11 cases). 4/19 (21\%) cases were diagnosed with granulomatous pathology, while smears in 1 case were non-diagnostic. Conclusion: Conventional transbronchial needle aspiration cytology is an efficacious method used for the diagnosis of lung carcinoma. Especially in resource-limited settings, it remains irreplaceable as a diagnostic tool and should be routinely utilized.

Keywords: Bronchoscopy, Lung cancer, Transbronchial needle aspiration

Corresponding Author

Deepti Arora, Associate Professor, Department of Pathology, Teerthanker Mahaveer Medical College and Research Center, Moradabad, Uttar Pradesh, India. Email: deepti.a15@gmail.com
How to Cite this Article

To Browse

Chauhan R, Awasthi S, Arora D, Ahmed F, Joshi H, Garg I. Conventional transbronchial needle aspiration cytology as a diagnostic tool in patients with suspected lung cancer - Our experience at a tertiary care center.. Trop J Pathol Microbiol. 2020;6(7):417424.

Available From

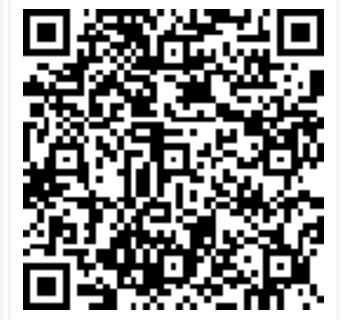

https://pathology.medresearch.in/index.php/jopm/ar ticle/view/479

Manuscript Received 2020-09-03

Conflict of Interest No
Review Round 1 2020-09-17

Funding

$\mathrm{Nil}$

Review Round 2
2020-09-22
Ethical Approval
Yes

Review Round 3

Plagiarism X-checker $9 \%$
Accepted 2020-10-07

Note

(C) 2020 by Rashmi Chauhan, Seema Awasthi, Deepti Arora, Faiyaz Ahmed, Himanshu Joshi, Ina Garg and Published by Siddharth Health Research and Social Welfare Society. This is an Open Access article licensed under a Creative Commons Attribution 4.0 International License https://creativecommons.org/licenses/by/4.0/ unported [CC BY 4.0] 


\section{Introduction}

According to GLOBOCAN 2018, lung cancer is the most common malignancy as well as the leading cause of cancer mortality worldwide [1]. It is the 4th most commonly detected cancer in India, with 67795 new cases reported in 2018 [2]. The prevalence and mortality in India appear to be rising due to an increase in cigarette smoking, changes in lifestyle, and environmental pollution [3].

A myriad of diagnostic modalities is available to diagnose lung malignancy at the earliest possible. Though radiological investigations like CT/PET can indicate the presence of a lesion in the lung and mediastinum, cell and tissue samples are needed in most cases to reach a more confirmatory diagnosis [4]. These samples can be collected through bronchoalveolar lavage, bronchial brushing, transbronchial needle aspiration cytology, and bronchial biopsy, that can be performed during bronchoscopy [5].

Cytology is a powerful tool in the diagnosis of lung malignancies as it is minimally invasive, less timeconsuming, and can provide a clear distinction between non-small cell and small cell lung carcinoma [6,7]. Transbronchial needle aspiration (TBNA) is one such minimally invasive technique used to obtain cytological samples from pulmonary lesions present in a peribronchial location (adjacent to a tracheobronchial tree), as well as from hilar and mediastinal lymph nodes [8]. TBNA provides a diagnosis even in the absence of endobronchial disease [9].

TBNA was first developed in 1949, to be used with rigid bronchoscopy [10]. In 1983, the use of TBNA with a flexible bronchoscope was described in detail by Wang et al [11] TBNA can be performed with or without real-time endobronchial ultrasound guidance (EBUS-TBNA). TBNA without EBUS is called conventional TBNA (c-TBNA), which utilizes chest computed tomography to locate the lesion and is dependent on a thorough understanding of thoracic anatomy $[12,13]$. The present study aimed to assess the utility of conventional transbronchial needle aspiration cytology in terms of diagnostic yield, in patients with suspected lung cancer.

\section{Material and Methods}

Setting: This study was conducted in the Department of Pathology, in collaboration with the Department of Medicine, Teerthanker Mahaveer
Medical College and Research Center, Moradabad, Uttar Pradesh, India.

Duration and type of study: It was a retrospective analysis of conventional transbronchial needle aspiration smears submitted in the Department of Pathology from January 2017 to February 2020.

Sample size: A total of 22 cases were studied.

Inclusion Criteria: Patients who underwent flexible bronchoscopy along with c-TBNA for clinical and radiological suspicion of lung malignancy were included in the study.

Exclusion criteria: Patients in whom c-TBNA could not be performed with bronchoscopy due to any contraindication were excluded.

Data collection: Complete history, clinical examination, and radiological details of the patients were recorded. C-TBNA smears received in the cytopathology lab were retrieved and reviewed.

Procedure: Flexible bronchoscopy was performed by the pulmonologist on a daycare basis, under local anesthesia. 22 gauge needle was used for the TBNA procedure that was done in a conventional fashion, without any real-time sonographic guidance. 2-3 pricks were taken from the area of interest and the aspirate was smeared on 6-7 clean glass slides. 2 slides were immediately fixed in $95 \%$ ethanol and the rest were air-dried. Rapid on-site evaluation (ROSE) of smears was not done. The smears were then submitted to the cytopathology lab where these smears were stained by Giemsa, $\mathrm{H}$ and $\mathrm{E}$ and Ziehl- Neelsen stains and cytopathological analysis was performed.

Ethical consideration and permission: Informed written consent was obtained from the patients before the bronchoscopy procedure and they were aware that data could be used anonymously for scientific research purposes. No ethical issues were involved.

Statistical Analysis: Data obtained were compiled in the MS Excel sheet and were then analyzed using mean (SD), percentage, and graphic representation.

\section{Results}

Out of the total 22 cases included in the study, 15 $(68 \%)$ cases were males and $7(32 \%)$ cases were females, with a male to female ratio of $\sim 2: 1$. The age range of the study population was from 32 to 
85 years, mean age being 57.54 years. The majority of cases $(7 / 22,32 \%)$ belonged to the age group of 51-60 years. Figure 1 shows the distribution of the study population based on age and gender.

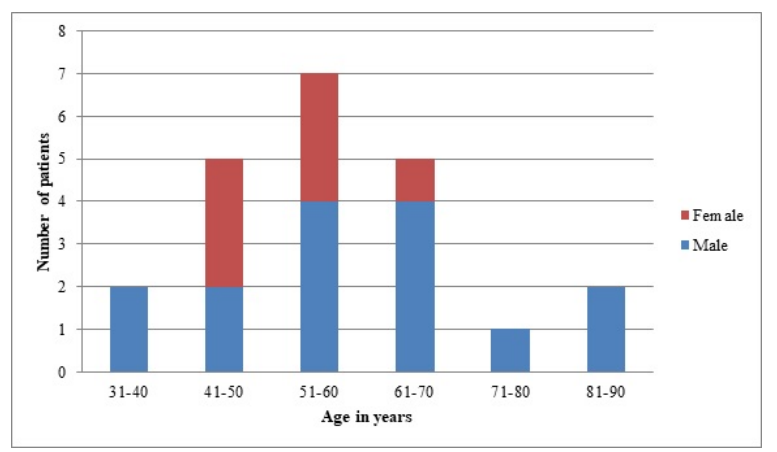

Fig-1: Age and sex distribution of cases.

The clinical profile of the patients showed cough as the most common clinical presentation (15/22, $68 \%)$, followed by weight loss $(12 / 22,54 \%)$ and shortness of breath $(8 / 22,36 \%)$. Additional clinical features included hemoptysis and fever (Table 1 ).

Table-1: Clinical profile of the study population.

\begin{tabular}{|l|l|l|}
\hline \multicolumn{1}{|c|}{ Clinical presentation } & \multicolumn{1}{c|}{ Number of cases $(\mathbf{n})$} & $(\%)$ \\
\hline Cough & 15 & $68 \%$ \\
\hline Weight loss & 12 & $54 \%$ \\
\hline Breathlessness & 08 & $36 \%$ \\
\hline Hemoptysis & 04 & $18 \%$ \\
\hline Fever & 05 & $22 \%$ \\
\hline
\end{tabular}

Microscopic examination of the received smears showed adequate material for cytopathological analysis in 19/22 cases (86\%). 3 cases were found unsatisfactory due to inadequate yield (Figure 2). 1 case had scant aspirate and the other 2 showed only blood as the aspirated material. Cytopathology of the c-TBNA smears was diagnostic in 18 out of 19 adequately aspirated cases.

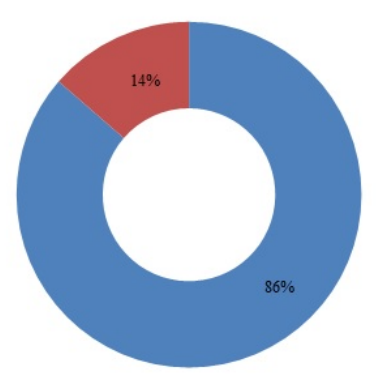

- Adequate aspirate - Inadequate aspirate

Fig-2: Adequacy of c-TBNA aspirate.
TBNA cytology was positive for malignancy in $14 / 19$ (74\%) cases. Cytological features in 4/19 (21\%) cases led to a benign diagnosis, with no evidence of malignancy. No definite diagnosis could be made in 1 case because of dense non-specific inflammatory infiltrate as the only cytological finding (Figure 3 ). The overall diagnostic yield of $c$-TBNA was found to be $82 \%$.

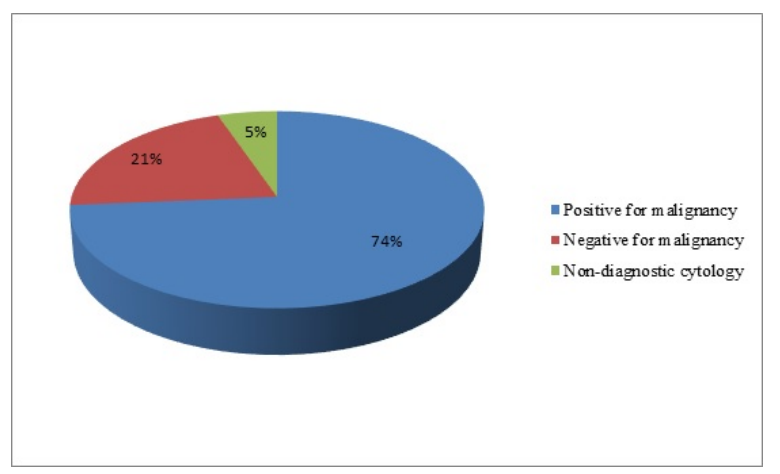

Fig-3: Cytology of adequate c-TBNA smears.

Non-small cell lung carcinoma was the most common malignancy diagnosed (11 cases). Out of these 11 cases, 6 cases showed cytomorphological features consistent with squamous cell carcinoma and 5 cases were consistent with adenocarcinoma. 2 cases were diagnosed as small cell carcinoma. In 1 case, definite typing of malignancy could not be done on the basis of cytological findings only (Table 2).

Table-2: Final diagnosis reached on C-TBNA cytopathological analysis.

\begin{tabular}{|c|c|c|}
\hline \multicolumn{2}{|c|}{ Patients with adequate aspirate on C-TBNA } & $19 / 22$ \\
\hline \multicolumn{2}{|c|}{ C-TBNA positive for malignancy } & $14 / 19$ \\
\hline \multicolumn{2}{|c|}{ 1. Non-small cell lung carcinoma } & 11 \\
\hline & Adenocarcinoma & 5 \\
\hline & Squamous cell carcinoma & 6 \\
\hline \multicolumn{2}{|c|}{ 2. Small cell carcinoma } & 2 \\
\hline \multicolumn{2}{|c|}{ 3. Malignant, typing not possible } & 1 \\
\hline \multicolumn{2}{|c|}{ C-TBNA negative for malignancy } & $4 / 19$ \\
\hline $\begin{array}{l}\text { 1. Confirmed } \\
\text { Tuberculosis }\end{array}$ & AFB - Positive & 1 \\
\hline $\begin{array}{l}\text { 2. Probable } \\
\text { Tuberculosis }\end{array}$ & $\begin{array}{l}\text { A necrotizing granulomatous lesion, AFB- } \\
\text { negative }\end{array}$ & 2 \\
\hline \multicolumn{2}{|c|}{ 3. Sarcoid like granulomatous lesion } & 1 \\
\hline \multicolumn{2}{|c|}{ c-TBNA with adequate aspirate but non-diagnostic cytology } & $1 / 19$ \\
\hline
\end{tabular}

Amongst the c-TBNA smears- negative for malignancy, 1 case showed necrotizing epithelioid cell granulomas and was found positive for acid-fast bacilli (AFB) on Ziehl- Neelsen staining. This was confirmed as a case of tuberculosis. 
2 cases showing necrotizing granulomas, but with negative AFB, were diagnosed as probable tuberculosis. Smears in 1 case revealed nonnecrotizing, compact, sarcoid like granulomas, negative for AFB and fungal stains, and a presumptive diagnosis of sarcoidosis was given, taking clinical and radiological features, tuberculin negativity, and ACE levels into consideration.

\section{Discussion}

Bronchoscopic evaluation is amongst the primary standard of care diagnostic procedures for patients with pulmonary and mediastinal pathologies. Conventional transbronchial needle aspiration can be easily combined with routine flexible bronchoscopy if the pulmonologist is aware of the radiological location of the lesion and has a good understanding of anatomical landmarks of the lungs and tracheobronchial tree. Hence, c-TBNA does not exactly remain a 'blind' procedure, in hands of a skilled and experienced pulmonologist, as is generally considered [13]. Despite this, c-TBNA remains an underutilized diagnostic technique, owing to concerns about its diagnostic yield $[8,14]$.

The current study analyzed the data of 22 conventional TBNA cases received in our department. Previous studies have had a variable mean age of presentation of the study population, ranging from as low as 39 years [15] to 65 years $[16,17]$. The mean age in the present study was 57.54 years, which was similar to studies of Kupeli et al [18], Walia et al [19], Darjani et al [20], and Farrag et al [21]. This variation in mean age can be due to the marked difference in the number of cases in various studies.

Sample adequacy of $80-90 \%$ was observed in various studies [20,22-24] similar to $86 \%$ in the present study. Cetinkaya et al [15] and Farrag et al [21] showed higher adequacy rates of $98 \%$ and $96.6 \%$ respectively, while those in studies of Walia et al [19] and Ramieri et al [16] were less than $60 \%$. The overall diagnostic yield of c-TBNA in the present study was found to be $82 \%$ which was either comparable to or higher than many other studies (Table-3).

Table-3: Diagnostic yield of c-TBNA in various studies.

\begin{tabular}{|l|l|}
\hline \multicolumn{1}{|c|}{ Study } & \multicolumn{1}{c|}{ Diagnostic yield } \\
\hline Present study & $82 \%$ \\
\hline Cetinkaya et al [15] & $75 \%$ \\
\hline
\end{tabular}

\begin{tabular}{|l|l|}
\hline Kupeli et al [18] & $44.4 \%$ \\
\hline Walia et al [19] & $42.3 \%$ \\
\hline Darjani et al [20] & $55.26 \%$ \\
\hline Farrag et al [21] & $88.3 \%$ \\
\hline Madan et al [23] & $78 \%$ \\
\hline Shah et al [24] & $83 \%$ \\
\hline Soja et al [25] & $41.5 \%$ \\
\hline Chokhani R [26] & $88.2 \%$ \\
\hline Khan et al [27] & $40.5 \%$ \\
\hline Kumari et al [28] & $54.38 \%$ \\
\hline
\end{tabular}

Wide variation in diagnostic yield observed in different studies has been attributed to difference in the prevalence of nodal metastasis in the study group, [29] size of the involved lymph nodes, $[21,30,31]$ selective aspiration of subcarinal and paratracheal lymph nodes [32], and use of different bore needles to obtain the specimen $[17,27,33]$. The skill and experience of the bronchoscopist performing the procedure also play an important role. C-TBNA has a short and steep learning curve [34] and its diagnostic yield is noticed to improve over time with practice $[18,19,22,35]$.

The presence of a pathologist on-site to perform rapid on-site cytopathological evaluation (ROSE) of the smears has been shown to improve the diagnostic yield of c-TBNA $[23,34,36,37]$. But some studies failed to detect this improvement with ROSE as significant [38]. ROSE was not performed in current study, but the diagnostic yield was still comparable to other studies in which C-TBNA was done along with the onsite evaluation of the aspirate $[16,23]$. Farrag et al $[21]$ also observed the findings similar to the present study. Therefore, the emphasis is laid on performing c-TBNA even if ROSE is not possible because of the unavailability of a cytopathologist.

Some studies have compared conventional versus EBUS-guided TBNA and showed that ultrasound guidance increases the yield of TBNA $[30,39,40]$. However, the diagnostic yields obtained by c-TBNA were found similar to ultrasound-guided TBNA in the subcarinal and lower paratracheal lymph nodes $[40,41]$. Bonifazi et al also did not find the sensitivity of EBUS-TBNA as significantly superior to that of c-TBNA [17]. So, there is no reason to undermine the importance of c-TBNA as a diagnostic test, especially in absence of newer modalities. Studies have shown that TBNA cytology can be used in pathological diagnosis and typing of pulmonary and mediastinal neoplasms, diagnosis of unknown hilar/mediastinal lymphadenopathy, and in the staging of lung cancer patients $[8,16,30,32,33]$. 
In the present study, $74 \%$ of cases were found positive for malignancy, while in $21 \%$ of cases a benign diagnosis was made.

Cytological typing of malignancy was possible in $13 / 14$ cases, the majority being non-small cell lung carcinoma, similar to most other studies $[19,21,27]$. Darjani et al reported small cell carcinoma as the most common malignancy [20].

It was found that squamous cell carcinoma was the most common subtype diagnosed, similar to the studies of Walia et al [19] and Kumari et al [28] whereas adenocarcinoma was more commonly reported in studies of Ramieri et al [16] and Bonifazi et al [17]. This variation in a pathological profile can be explained by the prevalence of different types of lung malignancies in different geographical regions [42].

The present study also showed a possibility of obtaining non- malignant diagnosis on c-TBNA done in face of initial suspicion of malignancy, similar to the study of Walia et al [19]. The present study, 4 cases with granulomatous pathology were diagnosed, out of which 3 were tuberculosis and 1 was sarcoidosis.

Granulomas can be identified on TBNA cytology in a reliable manner [43]. However, higher TBNA yield has been noted for carcinoma when compared to benign lesions $[15,30]$. Still, TBNA can be considered a valuable method to obtain a cytological specimen for diagnosing malignancy as well as tuberculosis and sarcoidosis in intrathoracic lymph nodes $[15,44]$.

\section{Limitation}

The limitation of this study is that the sample size was small. So, it is recommended that the same study should be conducted on a large number of cases so that concrete evidence could be derived on the efficacy of c-TBNA as an early diagnostic tool.

\section{Conclusion}

Conventional transbronchial needle aspiration cytology is an efficacious technique used for the diagnosis of lung carcinoma. It can provide good results in hands of a skilled bronchoscopist and cytopathologist. In developing countries like India, where resources are limited and affordability of medical facilities is a major concern, c-TBNA remains irreplaceable as a diagnostic tool.
Therefore, it is emphasized that the more enthusiastic use of this technique is necessary so that no patient misses the opportunity to early diagnosis due to the unavailability of more advanced technologies.

\section{What does this study add to the existing knowledge}

The current study highlights c-TBNA as a promising, simple, and easy diagnostic modality for early diagnosis of lung cancer, even in this era of new advances in bronchoscopic procedures.

\section{Authors' contribution}

Dr. Rashmi Chauhan: Concept and design of the study, manuscript preparation, analysis, and interpretation of data.

Dr. Seema Awasthi: Data analysis, manuscript review, final approval of the version to be published.

Dr. Deepti Arora, Dr. Faiyaz Ahmed, Dr. Himanshu Joshi, Dr. Ina Garg: Data acquisition, literature search, manuscript editing, and review.

\section{Reference}

01. Bray F, Ferlay J, Soerjomataram I, Siegel RL, Torre LA, Jemal A. Global cancer statistics 2018GLOBOCAN estimates of incidence and mortality worldwide for 36 cancers in 185 countries. CA Cancer J Clin. 2018;68(6)394-424.

doi: $10.3322 /$ caac.21492 [Crossref]

02. Dar M, Sharma K. Burden of cancer in IndiaGLOBOCAN 2018 Estimates, Incidence, Mortality, prevalence and future projections of cancer in India. J Emerg Technol Innovat Res. 2019;6(6)505-514.

[Crossref]

03. Islami F, Torre LA, Jemal A. Global trends of lung cancer mortality and smoking prevalence. Transl Lung Cancer Res. 2015;4(4)327-338. doi: $10.3978 /$ j.issn.2218-6751.2015.08.04 [Crossref]

04. Figueiredo $V R$, Jacomelli $M$, Rodrigues $A J$, Canzian M, Cardoso PF, Jatene FB. Current status and clinical applicability of endobronchial ultrasound-guided transbronchial needle aspiration. J Bras Pneumol. 2013;39(2)226-237. doi: $10.1590 / s 1806-37132013000200015$ [Crossref] 
05. Prakash UB, Offord KP, Stubbs SE. Bronchoscopy in North America the ACCP survey. Chest. 1991;100(6)1668-1675. doi: $10.1378 /$ chest.100.6.1668 [Crossref]

06. Stanley JH, Fish GD, Andriole JG, et al. Lung lesions- cytologic diagnosis by fine-needle biopsy. Radiology. 1987;162(2)389-391.

doi: $10.1148 /$ radiology.162.2.3797651 [Crossref]

07. Delgado PI, Jorda M, Ganjei-Azar P. Small cell carcinoma versus other lung malignanciesdiagnosis by fine-needle aspiration cytology. Cancer. 2000;90(5)279-285.

[Crossref]

08. Bilaceroglu S, Chhajed P. Transbronchial needle aspiration- A diagnostic tool in routine bronchoscopy. J Assoc Physicians India. 2005;53;797-802.

[Crossref]

09. Herth FJ, Rabe KF, Gasparini S, Annema JT. Transbronchial and transoesophageal (ultrasound-guided) needle aspirations for the analysis of mediastinal lesions. Eur Respir J. 2006;28(6)1264-1275.

doi: $10.1183 / 09031936.00013806 \quad$ [Crossref]

10. Schieppati E. La puncion mediastinal a traves del espolon traqueal, [Trans-tracheal aspiration of the mediastinum]. Rev As Med Argent. $1949 ; 663 ; 497-499$.

[Crossref]

11. Wang KP, Terry PB. Transbronchial needle aspiration in the diagnosis and staging of bronchogenic carcinoma. Am Rev Respir Dis. $1983 ; 127(3) 344-347$.

doi: $\quad 10.1164 /$ arrd.1983.127.3.344 [Crossref]

12. Liu QH, Ben SQ, Xia Y, Wang KP, Huang HD. Evolution of transbronchial needle aspiration technique. J Thorac Dis. 2015;7(S4)S224-S230. doi: $10.3978 /$ j.issn.2072-1439.2015.11.31 [Crossref]

13. Yang $H$, Zhang $Y$, Wang KP, Ma Y. Transbronchial needle aspiration: development history, current status and future perspective. J Thorac Dis. 2015;7(S4)S279-S286.

doi: $10.3978 /$ j.issn.2072-1439.2015.11.36 [Crossref]
14. Dasgupta A, Mehta AC. Transbronchial needle aspiration- An underused diagnostic technique. Clin Chest Med. 1999;20(1)39-51.

doi: $10.1016 / \mathrm{s} 0272-5231(05) 70125-8 \quad$ [Crossref]

15. Cetinkaya E, Yildiz $P$, Altin S, Yilmaz V. Diagnostic value of transbronchial needle aspiration by Wang 22-gauge cytology needle in intrathoracic lymphadenopathy. Chest. 2004;125(2)527-531.

doi: $10.1378 /$ chest.125.2.527 [Crossref]

16. Ramieri MT, Marandino F, Visca $P$, Salvitti $T$, Gallo E, Casini B, et al. Usefulness of conventional transbronchial needle aspiration in the diagnosis, staging and molecular characterization of pulmonary neoplasias by thin-prep based cytology- experience of a single oncological institute. J Thorac Dis. 2016;8(8)2128-2137.

doi: $10.21037 /$ jtd.2016.07.62 [Crossref]

17. Bonifazi M, Tramacere I, Zuccatosta L, Mei F, Sediari M, Paonessa MC, et al. Conventional versus Ultrasound-Guided Transbronchial Needle Aspiration for the Diagnosis of Hilar/Mediastinal Lymph Adenopathies- A Randomized Controlled Trial. Respiration. 2017;94(2)216-223.

doi: $10.1159 / 000475843$ [Crossref]

18. Küpeli E, Seyfettin P, Tepeoğlu MD. Conventional transbronchial needle aspiration- From acquisition to precision. Ann Thorac Med. 2015;10(1)50-54. doi: 10.4103/1817-1737.146873 [Crossref]

19. Walia R, Madan K, Mohan A, Jain D, Hadda V, Khilnani GC, et al. Diagnostic utility of conventional transbronchial needle aspiration without rapid on-site evaluation in patients with lung cancer. Lung India. 2014;31(3)208-211. doi: 10.4103/0970-2113.135754 [Crossref]

20. Darjani HR, Kiani A, Bakhtiar M, Sheikhi N. Diagnostic Yield of Transbronchial Needle Aspiration (TBNA) for Cases with Intra-Thoracic Lymphadenopathies. Tanaffos. 2011;10(4)4348.

[Crossref] 
21. Farrag MA, El Assal GM, Madkour AM, Osman NM, Taha MH. Implementation of bronchoscopic conventional transbronchial needle aspiration service in a tertiary care chest hospital. Egypt J Bronchol. 2019;13(3)309-313.

doi: 10.4103/ejb.ejb_95_18 [Crossref]

22. Tutar N, Büyükoğlan H, Yılmaz İ, Kanbay A, Önal Ö, Bilgin $M$, et al. Learning curve of conventional transbronchial needle aspiration. Clin Respiratory J. 2014;8(1)79-85. doi: $10.1111 /$ crj.12041 [Crossref]

23. Madan NK, Madan K, Jain D, Walia R, Mohan A, Hadda $V$, et al. Utility of conventional transbronchial needle aspiration with rapid onsite evaluation (c-TBNA-ROSE) at a tertiary care center with endobronchial ultrasound (EBUS) facility. J Cytol. 2016;33(1)22-26.

doi: 10.4103/0970-9371.175493 [Crossref]

24. Shah UC, Baby UR, Shah AC, et al. Conventional TBNA with 19 G TBNA needle in diagnosis of mediastinal lymph nodes - diagnostic yield and safety with 19G TBNA needle. Int J Contemp Med Res. 2020;7(2)B13-B16.

doi: 10.21276/ijcmr.2020.7.2.49 [Crossref]

25. Soja J, Szlubowski A, Wasowski D, Kuzdzal J, Zieliński M, Sładek K. Transbronchial needle aspiration as a diagnostic method of mediastinal adenopathy. Przegl Lek. 2005;62(2)102-104.

[Crossref]

26. Chokhani R. Transbronchial needle aspiration in the diagnosis of respiratory diseases. Nepal Med Coll J. 2004;6(1)24-27.

[Crossref]

27. Khan A, Agarwal R, Aggarwal AN, Gupta N, Bal $A$, Singh $N$, et al. Blind transbronchial needle aspiration without an on-site cytopathologistexperience of 473 procedures. Natl Med J India. 2011;24(3)136-139.

[Crossref]

28. Kumari A, Gupta M, Abhesheik. Diagnostic yield of TBNA and bronchial biopsy in lung cancer. Int J Res Med Sci. 2017;5(8)3708-3712.

doi: $10.18203 / 2320-6012$. ijrms20173590 [Crossref]
29. Holty JE, Kuschner WG, Gould MK. Accuracy of transbronchial needle aspiration for mediastinal staging of non-small cell lung cancer- A metaanalysis. Thorax. 2005;60(11)949-955.

doi: $10.1136 /$ thx.2005.041525 [Crossref]

30. Punamiya V, Mehta A, Chhajed P. Bronchoscopic needle aspiration in the diagnosis of mediastinal lymphadenopathy and staging of lung cancer. J Cancer Res Ther. 2010;6(2)134-141. doi: 10.4103/0973-1482.65231 [Crossref]

31. Chin R Jr, Mc Cain TW, Lucia MA, Cappellari JO, Adair NE, Lovato JF, et al. Transbronchial needle aspiration in diagnosing and staging lung cancer- How many aspirates are needed?. Am J Respir Crit Care Med. 2002;166(3)377-381.

doi: 10.1164/rccm.2106153 [Crossref]

32. Harrow EM, Abi-Saleh W, Blum J, Harkin T, Gasparini S, Addrizzo-Harris DJ, et al. The utility of transbronchial needle aspiration in the staging of bronchogenic carcinoma. Am J Respir Crit Care Med. 2000;161(2 Pt 1)601-607.

doi: $\quad 10.1164 /$ ajrccm.161.2.9902040 [Crossref]

33. Schenk DA, Chambers SL, Derdak S, Komadina $\mathrm{KH}$, Pickard JS, Strollo PJ, et al. Comparison of the Wang 19-gauge and 22-gauge needles in the mediastinal staging of lung cancer. Am Rev Respir Dis. 1993;147(5)1251-1258.

doi: $10.1164 /$ ajrccm/147.5.1251 [Crossref]

34. Mehta AC, Wang KP. Teaching conventional transbronchial needle aspiration- A continuum. Ann Am Thorac Soc. 2013;10(6)685-689. doi: 10.1513/AnnalsATS.201308-272ED [Crossref]

35. Kupeli E, Memis L, Ozdemirel TS, Ulubay G, Akcay S, Eyuboglu FO. Transbronchial needle aspiration "by the books". Ann Thorac Med. 2011;6(2)85-90.

doi: $10.4103 / 1817-1737.78427$ [Crossref]

36. Baram D, Garcia RB, Richman PS. Impact of rapid on-site cytologic evaluation during transbronchial needle aspiration. Chest. 2005;128(2)869-875.

doi: 10.1378/chest.128.2.869 [Crossref] 
37. Diette GB, White $P$ Jr, Terry $P$, Jenckes $M$, Rosenthal D, Rubin HR. Utility of on-site cytopathology assessment for bronchoscopic evaluation of lung masses and adenopathy. Chest. $2000 ; 117(4) 1186-1190$.

doi: $10.1378 /$ chest.117.4.1186 [Crossref]

38. Trisolini R, Cancellieri A, Tinelli C, Paioli D, Scudeller L, Casadei GP,et al. Rapid on-site evaluation of transbronchial aspirates in the diagnosis of hilar and mediastinal adenopathy- a randomized trial. Chest. 2011;139(2)395-401. doi: 10.1378/chest.10-1521 [Crossref]

39. Herth F, Hecker E, Hoffmann H, Becker HD. Endobronchial ultrasound for local tumour and lymph node staging in patients with centrally growing lung cancer. Ultraschall Med. 2002;23(4)251-255.

doi: $10.1055 / \mathrm{s}-2002-34056$ [Crossref]

40. Herth F, Becker HD, Ernst A. Conventional vs endobronchial ultrasound-guided transbronchial needle aspiration- a randomized trial. Chest. 2004;125(1)322-325.

doi: 10.1378/chest.125.1.322 [Crossref]
41. Naruke T, Tsuchiya $R$, Kondo $H$, Nakayama $H$, Asamura $H$. Lymph node sampling in lung cancer: How should it be done?. Eur J Cardiothorac Surg. 1999;16;S17-24. doi:10.1016/s1010-7940(99)00178-5 [Crossref]

42. Afrose R, Akram M, Karimi AM, Siddiqui SA. Correlation of age and gender with different histological subtypes of primary lung cancer. Med J DY Patil Univ. 2015;8;447-451.

[Crossref]

43. Cancellieri A, Leslie KO, Tinelli C, Patelli M, Trisolini R. Sarcoidal granulomas in cytological specimens from intrathoracic adenopathymorphologic characteristics and radiographic correlations. Respiration. 2013;85(3)244-251.

doi: $10.1159 / 000345386$ [Crossref]

44. Çetinkaya E, Yıldız P, Kadakal F, Tekin A, Soysal $\mathrm{F}$, Elibol $\mathrm{S}$, et al. Transbronchial needle aspiration in the diagnosis of intrathoracic lymphadenopathy. Respiration. 2002;69(4)335338.

doi: $10.1159 / 000063275$ [Crossref] 